\title{
Cattle Responses to Continuous and Seasonal Grazing of California Annual Grassland
}

\author{
RAYMOND D. RATLIFF
}

\section{Abstract}

An 8-year (1961-1968) study at the San Joaquin Experimental Range, in the Sierra Nevada foothills in central California, compared continuous, repeated seasonal, and rotated seasonal grazing on native range, and continuous grazing on sulfur-fertilized range. Cow and calf weight responses showed continuous grazing of annual grassland range to be most productive for cow-calf production. At birth, no advantage of one graxing treatment over another was found among calf weights. At the start of the adequate green forage season, calves under both continuous grazing treatments (native and fertilized) averaged $15 \mathrm{~kg}$ heavier than calves under rotated seasonal grazing; calves on continuously grazed fertilized range averaged $12 \mathrm{~kg}$ heavier than calves under repeated seasonal grazing. At weaning, calves under continuous grazing treatments averaged $25 \mathrm{~kg}$ heavier than calves under seasonal grazing treatments. No advantage of one grazing treatment over another was found among mature cow weights.

Overstocking their rangeland was the reason Abram and Lot parted ways (Genesis 13:2-11). The concept of periodically resting the land was set forth by Moses (Exodus 23:10-11, Leviticus 25:17). Centuries later specialized grazing management or grazing systems (Range Term Glossary Committee 1974) were set forth to maintain and improve rangeland.

Most current grazing systems are designed for managing perennial grasslands. Their purpose is to improve range condition through better livestock distribution, improved plant vigor, greater seed production and seedling establishment, and breaks in habitual use patterns.

Such grazing systems may be of little value in managing annual grasslands. Annual plants grow, produce seed, and die in a single year. They need not accumulate food reserves or maintain vigor. Nevertheless, annual plants do respond to factors of seed germination and seedling establishment. And grazing management can affect annual grassland species composition, herbage yield, and livestock production.

Can better cow and calf production be obtained on annual grassland under continuous yearling grazing or under some form of grazing system? Cows kept all year in a single range unit at the San Joaquin Experimental Range, Madera County, California, had lower pregnancy and weaning percentages than cows moved to ungrazed units in August (Wagnon et al. 1959). Both groups received supplemental feeding. A third group of cows (moved but unsupplemented) had fewer stillbirths and otherwise did as well as the cows not moved. Interpreting responses of the cows not moved was, however, complicated by possible and unusual trace-element deficiencies. Their responses, therefore, were not attributed solely to grazing the same range unit yearlong. The question remained.

This paper reports cow and calf weight responses from an 8-year (1961-1968) study intended to answer that question. Herbage

\footnotetext{
Author is range scientist, Pacific Southwest Forest and Range Experiment Station, Forest Service, U.S. Department of Agriculture, 2081 E. Sierra Ave., Fresno, Calif. 93710.

Many people were involved in this research. Specific recognition and thanks are due to: Stanley L. Anderson (range technician/herdsman), James L. Burns (maintenance foreman), C. Eugene Conrad (range scientist), Don A. Duncan (range scientist/project leader), Robert Flournoy (rancher/cooperator, Likely, California), Charles A. Graham (range scientist/superintendent), C. Dick Hansen (rancher/cooperator, Biola, California), Merton J. Reed (range scientist/project leader), Jack N. Repper (range scientist), Stanley E. Westfall (range technician), and E. Joseph Woolfolk (division chief/assistant director)

Manuscript accepted 10 April 1986
}

residue amounts and cow reproductive performance are also discussed.

\section{Methods}

\section{Experimental Area}

The San Joaquin Experimental Range occupies about 1,862 ha of annual grass-oak woodland in the Sierra Nevada foothills. Elevations range from 213 to $518 \mathrm{~m}$. Winters are relatively cool and wet. Summers are hot and dry.

Average (1934 to 1978) annual precipitation is $48.3 \mathrm{~cm}$. December, January, and February are the wettest months with 8.6,8.3, and 8.6 $\mathrm{cm}$, respectively. July and August are the driest months with 2.5 $\mathrm{mm}$. January is the coldest month with maximum and minimum temperatures averaging $11.8^{\circ} \mathrm{C}$ and $0.7^{\circ} \mathrm{C}$, respectively. July is the hottest month with maximum and minimum temperatures averaing $36.7^{\circ} \mathrm{C}$ and $16.2^{\circ} \mathrm{C}$, respectively.

Weather produces 3 characteristic forage seasons (Bentley and Talbot 1951). The "inadequate green" season begins after fall rains stimulate seed germination. During that forage season, environmental conditions usually limit plant growth. As a result, green forage is not of sufficient volume for cattle needs. Protein and energy supplements are usually necessary. The "adequate green" season begins in January or February when major grass species are 5 to $8 \mathrm{~cm}$ high. During that forage season, growth so accelerates that livestock cannot use all the herbage produced. The "dry" season begins when soil water becomes depleted in May or June. The annual plants produce seed and die. If it has cured well, dry season herbage may supply cattle with adequate protein and energy for several weeks.

\section{Grazing Treatments}

Historically, factors such as family tradition, ranch size, and available alternate forage have determined local practices. About half the operators (usually the larger ones) practiced a form of seasonal grazing. Cattle were taken to the higher mountains during the dry forage season. The home ranch was grazed continuously during the inadequate and adequate green forage seasons. Yearlong grazing, with some attempts at rotation, was the usual practice of small and part-time operators (Voorhies et al. 1942). Practices have changed little over the years.

This study compared continuous, repeated seasonal, and rotated seasonal grazing of native (unfertilized) range and continuous grazing of fertilized range. Elemental sulfur at $67 \mathrm{~kg} / \mathrm{ha}$ was applied to fertilized areas every third year.

Under continuous grazing, cattle have access to all of their range all year. In this paper, the continuous grazing treatments are abbreviated to "cont-N" and "cont- $F$ " for continuous grazing of native and fertilized range, respectively.

Under repeated seasonal grazing, cattle are on annual grassland range yearlong, but graze specifically restricted portions of their range during given forage seasons each year. Repeated seasonal grazing was studied by Wagnon et al. (1959) and Heady and Pitt (1979). Heady (1961) rotated the time (early, mid, late) of grazing during the growing season, but opened all areas to grazing during the dry and inadequate green forage seasons.

Under rotated seasonal grazing, cattle are on annual grassland range yearlong but graze specifically restricted portions of their range rotationally. The forage season of grazing is rotated among 
different portions of the range each year.

More efficient cattle production and better herbage production occur with moderate grazing than with close grazing on annual grassland (Bentley and Talbot 1951). Moderate grazing was therefore planned under all treatments.

\section{Range Units}

Swale, open-rolling, and rocky-brushy range site classes at the San Joaquin Experimental Range are described by Bentley and Talbot (1951) and Gaylord (1972). Productivity varies with site. Herbage production was therefore monitored for 2 years to determine and equalize grazing capacities.

The 4 treatments were then randomly assigned to 2 replications (blocks) of range units. One block of range units had about $26 \%$ open-rolling sites and $74 \%$ rocky-brushy sites. The other block of range units had about $89 \%$ rocky-brushy sites and $11 \%$ openrolling sites. The 8 range units average 91 ha in size. Range units assigned seasonal treatments were partitioned into 3 subunits for grazing in the 3 forage seasons.

\section{Supplemental Feeding}

To properly maintain their animals, ranchers in the area supplement dry and/or inadequate green herbage (Voorhies et al. 1942). Therefore, when quality herbage was in short supply, 4.5 $\mathrm{kg} /$ head/day of high quality alfalfa (Medicago sativa) hay was fed in all treatments. Iodized salt was provided in the last half of the gestation to prevent goiter in new-born calves. Block salt was provided as needed.

\section{The Cattle}

A select herd of 99 yearling Hereford heifers was brought to the San Joaquin Experimental Range in April 1959. All were of goodto-choice feeder grades, weighed 204 to $227 \mathrm{~kg}$, and were raised together. In November and December 1960, they had their first calves (Duncan and Reed 1973). In January 1961, balanced weight groups of 8 cows with calves were formed from the herd. The groups were randomly and permanently assigned to treatments and range units. The cows in the groups were called "testers."Their responses and those of their calves provided the measure of treatment effects. Other cows were put into and taken out of range units as needed to assure moderate use.

The breeding program was designed so that cows under all treatments would calve from late October to early December. Testers were culled if they twice failed to conceive and/or wean a calf, were sick for a protracted period, or, of course, died. To maintain a basic herd of 8 cows, culled testers were replaced.

At the change of forage seasons, cows were individually weighed following an overnight shrink. Calves were weighed within 24 hours of birth, when their dams were weighed, and at weaning.

\section{Herbage Production and Residue}

Herbage production by treatment was $3,100 \mathrm{~kg} / \mathrm{ha}$ under cont$\mathrm{F}, 2,390 \mathrm{~kg} / \mathrm{ha}$ under cont- $\mathrm{N}, 2,240 \mathrm{~kg} / \mathrm{ha}$ under repeated seasonal, and $2,460 \mathrm{~kg} /$ ha under rotated seasonal grazing (Caldwell et al. 1985; Caldwell, Menke and Duncan, unpublished manuscript).

At the start of the inadequate green forage season, 897 to 1,121 $\mathrm{kg} / \mathrm{ha}$ of herbage residue was to remain in continuously grazed range units and subunits grazed in the adequate green and dry forage seasons. Estimates of herbage residues were made along random, permanent transects, and sampling was proportional to the amount of a site class in a range unit. The overall average therefore estimated amounts left in the range unit or subunit. Residual herbage on subunits grazed in the inadequate green forage season was assumed to equal the herbage production.

\section{Analysis of Data}

Differences in cattle responses among grazing treatments were of primary interest. Owing to variation in the quantity and quality of forage, variation in cattle responses from year to year was expected. Therefore, mature cow weights (at weaning in 1964) and average calf weights (over the 8 years) expressed long-term responses to treatment. The analysis of variance model to estimate differences between treatments was a randomized complete-block design, with 1 observation per cell. Calf weights analyzed were those at birth, at the start of the adequate green forage season, and at the start of the dry forage season (the usual weaning time). Mature cow weights were analyzed using their initial weights at the start of the study as a covariate. Determining $95 \%$ confidence intervals for pairwise differences among treatment means was by Tukey's "w-procedure" (Steel and Torrie 1960). In this paper, differences between treatments are expressed as $(\bar{X} 1-\bar{X} 2) \pm \mathrm{w}$, where $w=Q$ (SE). $Q$ comes from tables for the number of means compared and error degrees of freedom.

\section{Results}

\section{Variation in the Green Forage Season}

Starting dates for the adequate green forage season (Table 1) varied from 12 January to 20 February. On the average, they were similar to those reported for the experimental range by Bentley and Talbot (1951).

Table 1. Adequate green forage season at the San Joaquin Experimental Range, Madera County, California (1961-1968).

\begin{tabular}{lllc}
\hline \hline & \multicolumn{2}{c}{ Dates } & $\begin{array}{c}\text { Length } \\
\text { (days) }\end{array}$ \\
\cline { 2 - 3 } Year & Start & End & 111 \\
\hline 1961 & Feb. 9 & May 31 & 119 \\
1962 & Feb. 20 & June 19 & 153 \\
1963 & Feb. 8 & July 11 & 155 \\
1964 & Jan. 15 & June 18 & 182 \\
1965 & Jan. 12 & July 13 & 98 \\
1966 & Feb. 15 & May 24 & 204 \\
1967 & Jan. 12 & Aug. 4 & 107 \\
1968 & Feb. 7 & May 24 & 141 \\
Average & Feb. 1 & June 22 & \\
\hline
\end{tabular}

Based on past ending dates (Bentley and Talbot 1951), the adequate green forage seasons in 1963, 1965, and 1967 ended later than usual. Those were 3 of 6 years from 1935 to 1978 in which April and May precipitation exceeded $10 \mathrm{~cm}$ and April, May, and June average maximum temperatures were below average. Late spring rains and low temperatures delayed the dry forage season.

\section{Grazing Use and Herbage Residue}

Based on the production estimates given earlier and leaving $1,121 \mathrm{~kg} / \mathrm{ha}$ of residue, grazing potentials were $1.1,1.8,1.2$, and 1.0 $\mathrm{AUM} /$ ha under cont-N, cont-F, rotated seasonal, and repeated seasonal grazing, respectively. Actual use by treatment was 1.1, $1.5,0.8$, and $0.7 \mathrm{AUM} / \mathrm{ha}$, respectively.

Differences among years in residual herbage amounts relate to

Table 2. Estimated plant residue prior to fall germination by graxing treatment at the San Joaquin Experimental Range, Madera County, California (1961-1967).

\begin{tabular}{|c|c|c|c|c|c|}
\hline \multirow[b]{3}{*}{ Year } & \multicolumn{5}{|c|}{ Grazing treatments } \\
\hline & \multicolumn{2}{|c|}{ Continuous } & \multicolumn{2}{|c|}{ Seasonal ${ }^{1}$} & \multirow[b]{2}{*}{ Average } \\
\hline & Native & Fertilized ${ }^{2}$ & Rotated & Repeated & \\
\hline & & -Kilc & grams per & ectare-. & \\
\hline 1961 & 701 & 805 & 495 & 441 & 610 \\
\hline 1962 & 432 & 459 & 414 & 440 & 436 \\
\hline 1963 & 984 & 1132 & 833 & 887 & 959 \\
\hline 1964 & 1542 & 1478 & 1301 & 1245 & 1392 \\
\hline 1965 & 1340 & 2282 & 1490 & 1201 & 1578 \\
\hline 1966 & 1124 & 1226 & 1391 & 1169 & 1228 \\
\hline 1967 & 1997 & 2786 & 2072 & 1900 & 2189 \\
\hline Average & 1160 & 1452 & 1142 & 1040 & 1199 \\
\hline
\end{tabular}

'Residue in the inadequate green forage season subunits was not included. ${ }^{2}$ Fertilized with mineral sulfur every third year. 
production and stocking. Average residue amounts range from $7 \%$ less to $30 \%$ more than planned (Table 2). Over all 7 years and all grazing treatments (excluding inadequate green forage season subunits), $7 \%$ more remained than planned. The lowest amount $(-63 \%)$ occurred under rotated seasonal grazing in 1962. The highest amount $(+148 \%)$ occurred under cont-F in 1967.

Residual herbage has little nutritional value after being leached by rain, and leaving an excess amount wastes resources. Under cont- $\mathrm{N}$ residual herbage averaged $39 \mathrm{~kg} / \mathrm{ha}$ more than planned. Under cont-F an excess of $331 \mathrm{~kg} / \mathrm{ha}$ remained. With additional cattle, another $0.3 \mathrm{AUM} / \mathrm{ha} / \mathrm{yr}$ could have been obtained under the treatment. Including the inadequate green forage season subunits, residual amounts were $1,440 \mathrm{~kg} / \mathrm{ha}(319 \mathrm{~kg} / \mathrm{ha}$ extra) under repeated seasonal grazing and $1,581 \mathrm{~kg} / \mathrm{ha}(460 \mathrm{~kg} / \mathrm{ha}$ extra $)$ under rotated seasonal grazing. Until the inadequate green forage season, a third of the production (one subunit) could not be used. It represents a loss of $0.3 \mathrm{AUM} / \mathrm{ha} / \mathrm{yr}$ under repeated seasonal grazing and $0.4 \mathrm{AUM} / \mathrm{ha} / \mathrm{yr}$ under rotated seasonal grazing.

Grazing use could probably have been heavier under all treatments during 1964, 1965, 1966, and 1967. Clawson et al. (1982) reported that 448 to $785 \mathrm{~kg} /$ ha of residual herbage (moderate use) produces the best cattle production on land like the San Joaquin Experimental Range. They also suggested minimum residual amounts of $448 \mathrm{~kg} / \mathrm{ha}$ for lower or flat slopes, $672 \mathrm{~kg} / \mathrm{ha}$ for average-gentle slopes, and $897 \mathrm{~kg} / \mathrm{ha}$ for upper or steep slopes. Over the years studied, therefore, any difference among grazing treatments in residual herbage levels should have had minimal influence on cow and calf weight responses.

Relative contributions of plant species to the herbage produced may change, however, due to treatment. Moreover, differences in cow and calf responses may reflect such changes. Plant species responses to cont-N, cont-F, and the seasonal grazing treatments have been discussed (Caldwell et al. 1985; Caldwell, Menke and Duncan, unpublished manuscript).

\section{Calf Response}

Over all years and treatments, calf birth weights at the San Joaquin Experimental Range (Table 3) averaged 31.0 $\pm 0.8 \mathrm{~kg}$. At

Table 3. Calf birth weights, weights at the start of the adequate green and dry forage seasons, and rates of gain during the adequate green forage season (over all treatments) by crop year at the San Joaquin Experimental Range, Madera County, California.

\begin{tabular}{lcccc}
\hline & \multicolumn{3}{c}{ Calf weights } & Green season \\
\cline { 2 - 5 } Year & Birth & Green season & Dry season & $\begin{array}{c}\text { Green per day } \\
\text { gain }\end{array}$ \\
\cline { 2 - 5 } 1961 & $28.1^{1}$ & 82.91 & 176.3 & 0.84 \\
1962 & 28.3 & 96.4 & 201.0 & 0.87 \\
1963 & 30.8 & 99.1 & 233.4 & 0.87 \\
1964 & 31.8 & 87.3 & 214.6 & 0.81 \\
1965 & 31.5 & 90.0 & 244.7 & 0.85 \\
1966 & 31.1 & 106.1 & 219.3 & 1.15 \\
1967 & 31.2 & 83.2 & 252.0 & 0.82 \\
1968 & 30.4 & 95.2 & 189.8 & 0.88 \\
Average & 31.0 & 94.8 & 217.8 & 0.89 \\
\hline
\end{tabular}

'For reader information; not used in analyses.

the start of adequate green forage, calves averaged $94.8 \pm 2.8 \mathrm{~kg}$. At weaning, the average calf weight was $217.8 \pm 4.3 \mathrm{~kg}$.

Calf weights at the start of the adequate green forage season reflect their ages more than inadequate green season forage quality. The calves were younger and weighed $90 \mathrm{~kg}$ or less when the adequate green forage season started in January. The calves were older and weighed over $90 \mathrm{~kg}$ when it started in February.

Variation in its length accounted for $90 \%(R=0.95)$ of the variation in calf weight gains (Table 3 ) during the adequate green forage season. The longer that calves were on the range, the greater their final weights. Calf gains also reflected forage quality. Though the 1966 season was short (98 days), the adequate green forage was of high quality. Calves gains $1.2 \mathrm{~kg}$ per day that season, $0.27 \mathrm{~kg}$ per day more than in any other year.

Larger calves are commonly asserted to have greater vitality at birth and to be larger at weaning than smaller calves. For calf birth weights (Table 4), the $95 \%$ confidence interval for the difference

Table 4. Calf birth weights and weights at the start of the adequate green and dry forage seasons by grazing treatment at the San Joaquin Expermental Range, Madera County, Califomia.

\begin{tabular}{lccc}
\hline \hline & \multicolumn{3}{c}{ Calf weights $^{\mathrm{l}}$} \\
\cline { 2 - 4 } Grazing treatment & Birth & Green season & Dry season \\
\hline & & & \\
Continuous & $31.9 \mathrm{a}$ & $100.4 \mathrm{ab}$ & $229.0 \mathrm{a}$ \\
$\quad$ Native & $31.9 \mathrm{a}$ & $101.0 \mathrm{a}$ & $227.8 \mathrm{a}$ \\
$\quad$ Fertilized & & & \\
Seasonal & $29.5 \mathrm{a}$ & $88.6 \mathrm{bc}$ & $205.2 \mathrm{~b}$ \\
$\quad$ Repeated & $29.7 \mathrm{a}$ & $86.2 \mathrm{c}$ & $202.2 \mathrm{~b}$ \\
$\quad$ Rotated & 3.3 & 12.2 & 18.6 \\
Tukey"s "w" & & & \\
\hline
\end{tabular}

${ }^{1}$ Within columns, treatment means followed by the same letter are not statistically different $(P<0.05)$.

${ }^{2}$ Fertilized with mineral sulfur every third year.

between the continuous grazing treatments and repeated seasonal grazing was $2.4 \pm 3.3 \mathrm{~kg}$. The true difference is, therefore, between an advantage of $0.9 \mathrm{~kg}$ for repeated seasonal grazing and an advantage of $5.7 \mathrm{~kg}$ for continuous grazing. At those extremes, an advantage for repeated seasonal grazing would little affect future calf response, but an advantage for continuous grazing could affect future calf response.

Continued supplementation after parturition should tend to reduce treatment differences in calf weights. Nevertheless, at the start of the adequate green forage season, calves under continuous grazing weighed more than calves under seasonal grazing (Table 4). Calves were $14.2 \pm 12.2 \mathrm{~kg}$ heavier under cont-N and $14.8 \pm$ $12.2 \mathrm{~kg}$ heavier under cont-F than calves under rotated seasonal grazing. Also, calves under cont-F were $12.4 \pm 12.2 \mathrm{~kg}$ heavier than calves under repeated seasonal grazing.

Treatment differences were amplified during the adequate green forage season. At the start of the dry forage season (the usual weaning time), calves under continuous grazing (Table 4) averaged $25 \mathrm{~kg}$ heavier than calves under seasonal grazing. Between cont- $\mathrm{N}$ and repeated and rotated seasonal grazing, the differences were $23.8 \pm 18.6 \mathrm{~kg}$ and $26.8 \pm 18.6 \mathrm{~kg}$, respectively. Between cont $-\mathrm{F}$ and repeated and rotated seasonal grazing, the differences were $22.6 \pm 18.6 \mathrm{~kg}$ and $25.6 \pm 18.6 \mathrm{~kg}$, respectively.

Similar results were reported by Duncan and Reed (1973). And continuous grazing gave better lamb weights and ewe performance than seasonal grazing of annual grassland (Heady 1961, Heady and Pitt 1979).

Cows under continuous grazing had the entire range unit for selecting forage. Those under seasonal grazing had one-third as much area. Consequently, although all cows received equal rations of hay, cows under continuous grazing had greater opportunity, after calving, to select diets conducive to high lactation rates. That may explain the heavier calves under continuous grazing at the start of the adequate green forage season.

Stocking rate differences during the adequate green forage season explain part of the difference in weaning weights between continuous and seasonal grazing treatments. Average stocking rates for cont- $\mathrm{N}$ and cont-F units were 2.3 and 1.9 ha/AUM, respectively. Average stocking rates for rotated and repeated seasonal subunits were 0.8 and 0.9 ha/AUM, respectively. Cows and calves under continuous grazing did not have to graze as closely as cows and calves under seasonal grazing. As a result, cows and calves under continuous grazing could be more selective in choos- 
Table 5. Starting and mature tester cow weights and $95 \%$ confidence intervals for the mean cow weights at the start of the dry forage season (1961-1968) on the San Joaquin Experimental Range, Madera County, California.

\begin{tabular}{|c|c|c|c|}
\hline $\begin{array}{l}\text { Grazing } \\
\text { treatment }\end{array}$ & $\begin{array}{l}\text { Starting } \\
\text { weight }\end{array}$ & $\begin{array}{l}\text { Mature } \\
\text { weight }{ }^{1}\end{array}$ & $\begin{array}{l}\text { Confidence } \\
\text { Interval }^{2}\end{array}$ \\
\hline & & -Kilogra & - \\
\hline \multicolumn{4}{|l|}{ Continuous } \\
\hline Native & 331.6 & $503.5 \mathrm{a}^{3}$ & $471.3 \pm 34.2$ \\
\hline Fertilized 4 & 339.7 & $518.7 \mathrm{a}$ & $492.8 \pm 36.0$ \\
\hline \multicolumn{4}{|l|}{ Seasonal } \\
\hline Repeated & 326.3 & $464.9 \mathrm{a}$ & $441.3 \pm 24.1$ \\
\hline Rotated & 336.8 & $459.4 a$ & $437.1 \pm 21.1$ \\
\hline \multirow{2}{*}{$\begin{array}{l}\text { Average } \\
\text { Tuckey's "w" }\end{array}$} & 333.6 & 486.6 & \\
\hline & & 146.4 & \\
\hline
\end{tabular}

'At weaning of calves (18 June 1964) and adjusted for covariate effects of starting weights (10 Jan. 1961).

${ }_{2}^{2}$ For reader information. Cows without calves were not included. Confidence intervals for individual treatment means should not be used to assess treatment effects.

${ }^{3}$ Within column, values followed by the same letter are not statistically different $(P<0.05)$.

4Fertilized with mineral sulfur every third year.

ing their diet (at least toward the end of the adequate green forage season).

\section{Cow Responses}

Weights of original tester cows that weaned calves in 1964 were used to estimate grazing treatment effects on the cows. Cow weights (taken on a specific date) summarize all influences from the start of the study. By 1965, many of the original testers in some range units had been replaced. Because their histories and those of the testers differed, replacement cow weights could not be used to reflect long-term treatment effects. Weights of all cows (replacements as well as testers) were used by Duncan and Reed (1973). The weights they reported therefore differ from those given here.

The $95 \%$ confidence interval for the difference in weights of mature cows (Table 5) under cont-F and those under rotated seasonal grazing, was $59.3 \pm 146.4 \mathrm{~kg}$. The true difference is, therefore, somewhere between an advantage of $87.1 \mathrm{~kg}$ for rotated seasonal grazing and an advantage of $205.7 \mathrm{~kg}$ for cont-F. Confidence intervals for other continuous and seasonal grazing comparisons may be similarly interpreted.

Ranchers commonly accept the premise that large cows produce large calves. Continuous grazing produced larger calves than seasonal grazing. Any true difference in cow weights is, therefore, likely an advantage for continuous grazing.

Fewer heifers may need be retained annually under rotated seasonal grazing. Over all years and grazing treatments, $34 \mathbf{( 7 . 1 \%}$ per year) of the original 64 cows were replaced. By treatment, replacements were $63 \%$ (cont-N), $56 \%$ (cont-F), 63\% (repeated seasonal), and $31 \%$ (rotated seasonal). For all treatments, except rotated seasonal, 1 or more replacement cows were replaced.
The overall weaning rate was 0.88 calf/cow. Average weaning rates were 0.85 (cont-N), 0.87 (repeated seasonal), 0.90 (cont-F), and 0.90 (rotated seasonal).

The overall conception rate was 0.95 calf/cow. Conception by treatment averaged 0.91 (cont- $N$ ), 0.95 (repeated and rotated seasonal), and 0.98 (con-F). The overall weaning rate per pregnant cows was 0.93 calf $/$ cow. Average weaning rates were 0.91 (repeated seasonal), 0.92 (cont-F), 0.94 (cont-N), and 0.95 (rotated seasonal).

\section{Conclusions}

For cow-calf operators dependent yearlong on annual grassland of the Sierra Nevada foothills, continuous grazing should be more productive than seasonal grazing. That conclusion is consistent with previous findings of livestock responses on annual grassland range. To maintain productivity of the resource base, stocking to obtain moderate use is recommended.

At the San Joaquin Experimental Range, calves on range grazed continuously were heavier at weaning than calves on range divided into seasonal units grazed repeatedly or in rotation. At a market price of $\$ 1.36 / \mathrm{kg}$, (based on the $95 \%$ confidence interval), the return per calf under continuous grazing on native range would be between $\$ 11.15$ and $\$ 61.74$ more than per calf under rotated seasonal grazing. Whether differences of those sizes will induce cowcalf operators to change from seasonal to continuous grazing depends on cost-return relationships.

\section{Literature Cited}

Bentley, J.R., and M.W. Talbot. 1951. Efficient use of annual plants on cattle ranges in the California foothills. USDA, Washington, D.C. Circ. No. 870.

Caldwell, R.M., J.W. Menke, and D.A. Duncan. 1985. Effects of sulfur fertilization on productivity and botanical composition of California annual grassland. J. Range Manage. 38:108-1 13.

Clawson, J.W., N.K. MeDougald, and D.A. Duncan. 1982. Guidelines for residue management on annual range. Cooperative Extension, Div. of Agr. Sci., Univ. Calif., Berkeley. Leafl. 21327.

Duncan, D.A., and M.J. Reed. 1973. Yearlong tops seasonal grazing in extended rangeland study. West. Livest. J. (Mt. Plains \& Southwest Ed.) $51: 32-48$.

Gaylord, V.J. 1972. A method for the correlation of range sites with land association classes in the Sierra foothills. M.S. Thesis, California State Univ., Fresno.

Heady, H.F. 1961. Continous vs. specialized grazing systems: A review and application to the California annual type. J. Range Manage. 14:182-193.

Heady, H.F., and M.D. Pitt. 1979. Seasonal versus continuous grazing on annual vegetation of northern California. Rangelands 1:231-232.

Range Term Glossary Committee. 1974. A glossary of terms used in range management. 2nd ed. Soc. for Range Manage. Denver, Colo.

Steel, R.G.D., and J.H. Torrie. 1960. Principles and procedures of statistics. McGraw-Hill, Inc., New York.

Voorhies, E.C., L.A. Crawford, R.L. Adams, and G.A. Carpenter. 1942. Ranch organization and management in the granite area. p. 83-95. In: C.B. Hutchison and E.I. Kotok (eds.), The San Joaquin Experimental Range. Univ. Calif., Berkeley. Bull. 663.

Wagnon, K.A., H.R. Guilbert, and G.H. Hart. 1959. Beef cattle investigations on the San Joaquin Experimental Range. California Agr. Exp. Sta. Bull. 765 . 